\title{
Proposed Strategy for Electricity Industry of PT PLN (Persero) Electricity Maintenance Center (PLN Pusharlis)
}

\author{
Rizka Malia Khulda and Harimukti Wandebori
}

\begin{abstract}
PT PLN (Persero) Electricity Maintenance Center, hereinafter referred to as PLN Pusharlis, is a PLN support unit that focuses on fulfilling roles in Reverse Engineering, Manufacturing and Quality Control of power plant equipment. Knowing that the government has launched the 35,000 MW program as an effort to realize public welfare and to overcome the shortage of electricity supply in areas with electricity deficit status, PLN Pusharlis has a role in fulfilling the electricity component. To realize this role, good internal company conditions are needed. However, on its internal conditions, it is known that $\mathbf{7 0 \%}$ of the total employees not yet possessing competency certification and currently, PLN Pusharlis has not linked its strategy with future roles to support the fulfillment of the electricity component for 35,000 MW program because the project has not been completed, while the role of PLN Pusharlis is to provide electricity components for existing generators. This research aims to identify and improve the PLN Pusharlis business strategy to support the fulfillment of the electricity component supported by good internal conditions. The conceptual framework used in this research begins with analyzing the external environment through PESTLE, Porter's Five Forces Model, and competitor analysis as well as internal environment through resource analysis, value chain analysis, and core competencies. Then the results of the external and internal analysis are summarized in a SWOT analysis to determine the TOWS Matrix which is used as a reference in determining the proposed strategy. The strategy that will be applied based on the results of this study is the Integrated Cost Leadership/Differentiation strategy. The development of this strategy is expected to assist PLN Pusharlis in increasing its role as a support service unit engaged in Reverse Engineering and Electrical Equipment Manufacturing.
\end{abstract}

Index Terms - Business Strategy, Electricity, Reverse Engineering, Integrated Cost Leadership/Differentiation.

\section{INTRODUCTION AND RESEARCH OBJECTIVES}

The national electricity condition until the end of 2018 shows that the total installed capacity of power plants nationally is 64,924.80 MW (based on the electricity statistics report published by the Secretariat General of Electricity in 2018). This number increased by $4.38 \%$ compared to the previous year with an installed capacity of 62,202.94 MW [1]. This shows that current electricity consumption continues to increase which is also indicated by the increasing number of customers. The increasing number of customers, the wider business area served, as well as the increasing demands of the community for speed

Published on August 20, 2020.

Rizka Malia Khulda, Bandung Institute of Technology, Indonesia. (email: rizka.malia@sbm-itb.ac.id)

Harimukti Wandebori, Bandung Institute of Technology, Indonesia.

(e-mail: harimukti@sbm-itb.ac.id) of service, electricity quality, and transaction accuracy, require PT PLN (Persero) or hereinafter referred to as PLN as a state-owned company that deals with all aspects of electricity in Indonesia to adjust the business processes and improve service products ahead of customer needs. Realizing the public welfare and to overcome the problem of power supply shortages in areas with electricity deficit status, the government launched the "35,000 MW Program for Indonesia". This becomes a big responsibility not only for PLN but also for other PLN work units such as PT PLN (Persero) Electricity Maintenance Center or hereinafter referred to as PLN Pusharlis. PLN Pusharlis focuses on fulfilling roles in Reverse Engineering, Manufacturing, and Quality Control of power plant equipment. Currently, the reverse engineering method is being promoted by the government to support Indonesia to achieve an "innovationdriven economy" [2] and become a nation-based research and innovation national industry, where innovation can be achieved through three ways namely research, design engineering, and reverse engineering.

\section{A. Statement of the Problem}

Knowing the Government launched the 35,000 MW program, PLN Pusharlis has a role in fulfilling the electricity part. Realizing this role, good internal company conditions such as the quality of human resources and the assignment mechanism are needed. In terms of resources, it is known that $70 \%$ of the total number of employees not yet possessing competency certification both related to process, product, marketing, and support thus causing a reduction in competencies owned by PLN Pusharlis in running its business and affecting the process of achieving the targets set by PLN, then until the end of 2018 there was still no completion of the assignment process on time, this happens because the assignment trend received by PLN Pusharlis continues to increase. Also, PLN Pusharlis has not linked the current strategy to its future role in supporting the fulfillment of the electricity portion of the 35,000 MW program because the project has not been completed while the role of PLN Pusharlis is to provide electricity parts for existing power plants.

\section{B. Research Objectives}

This study aims to determine the appropriate strategy that can be carried out by PLN Pusharlis strategy to support the fulfillment of the electricity part of the current 35,000 MW program, seeing the role taken from PLN Pusharlis is to provide electricity parts that have been damaged by using the reverse engineering method. 


\section{Research Methodology}

The research method used in this study is a literature study, analytical management tools, and supporting data related to this study. A literature study is obtained from books. Analytical management tools are obtained from the company's environmental analysis both external and internal conditions, where analyzing the external environment using several tools such as PESTLE Analysis, Porter's 5 Forces Model, and competitor analysis, as well as internal environment analysis through resource analysis, value chain analysis, and core competencies. Then the results of the external and internal analysis are summarized in the SWOT analysis which will be used to determine strategy development. While supporting data is obtained from related company reports, interviews with interested parties, and officially published reports such as the Ministry of Energy and Mineral resources.

\section{EXTERNAL ANALYSIS}

External analysis is carried out to determine the opportunities and threats that occur, both in the macroenvironment, industry, and competition. External analysis in this study is carried out through PESTLE Analysis and Porter's 5 Forces analysis.

\section{A. PESTEL Analysis}

\section{Political/Legal}

The government supports the application of reverse engineering because it is a form of acceleration of Indonesia in innovation. Reverse engineering in the electricity industry is regulated in Government Regulations as stated in Presidential Regulation of the Republic of Indonesia Number 4 of 2016 (has been changed to Number 14 of 2017) concerning the Acceleration of Electricity Infrastructure Development as listed in Chapter IV regarding the Use of Domestic Goods/Services article 15 paragraph (2) which reads, "The use of domestic goods/services as referred to in paragraph (1) is carried out through a) the application of the open book system; b) granting price preferences, or c) reverse engineering." Other than that, the government, especially BPPT (Agency for Assessment and Application of Technology) supports Indonesia to become a nation-based research and innovation industry, where innovation can be achieved in three ways, namely research, design engineering, and reverse engineering.

The act of reverse engineering (reengineering) according to the Trade Secret Act (UURD) is an act of analysis and evaluation to find out the information about existing technology. The UURD does not consider violations of Trade Secrets to reverse engineering activities when reengineering of products resulting from the use of Trade Secrets of others is carried out solely for the benefit of further development.

\section{Economic}

The Indonesian economy is currently at an economic level based on increasing efficiency. This needs to be encouraged to achieve economic levels based on innovation and sophistication so that we can catch up and create leaps and bounds. Knowing that Indonesia is currently accelerating the achievement of an "innovation-driven economy", it requires innovation that can be part of economic growth, where one of its forms is without having to do basic research but by the application of reverse engineering as an acceleration. According to the Head of the Agency for the Assessment and Application of Technology (BPPT), that in the US, new inventions that have succeeded in becoming products of innovation are only five percent of existing inventions. While the application of reverse engineering can drive the success of new product innovations by $80 \%$. Developed countries penetrate the Gross Domestic Product (GDP) per capita at 12,000 USD while Indonesia is at aDP of 3,604 USD, and China is around 8,000 USD.

According to Minister of Finance Sri Mulyani, to increase the value of GDP requires a large investment, while to attract investors, infrastructure development and the quality of human resources must be improved [3]. This is in line with the needs of Indonesia if it wants to become a developed country through reverse engineering activities, which according to the Head of the Assessment and Application of Technology Agency (BPPT) Superior Priyanto in the law-justice.co article said that reverse engineering can encourage Indonesia to become a developed country so that basic research is not required and according to him Indonesia still has the opportunity to produce innovation because Indonesia is still experiencing a demographic bonus until 2030 (total population of productive age $>$ total population of unproductive age) so it needs to increase human resources to give birth to various innovations.

\section{Socio-Cultural}

Reverse engineering is a multidisciplinary approach and almost certainly can be applied to all fields of industry universally. The main consideration of the application of reverse engineering is to bring back copies of the original part or trace back what events have occurred. Reverse engineering is widely applied in the industrial world, such as thousands of parts successfully reappeared every year by using reverse engineering to meet the demands of a multibillion-dollar market. Digital reverse engineering applications continue to penetrate various fields such as the home industry, the medical industry, the food industry, any industry will undoubtedly be increasingly developed and increasingly personal and custom. Considering that PLN Pusharlis is the only PLN unit engaged in manufacturing using reverse engineering, it is expected to have a major contribution to the PLN economy which will have an impact on the Indonesian economy.

\section{Technology}

Technological developments have affected all sectors of life, including the manufacturing industry. According to the Head of the Agency for the Assessment and Application of Technology (BPPT) Unggul Priyanto in the law-justice.co article said that reverse engineering can push Indonesia to become a developed country so that basic research is not necessary. Reverse engineering is a leap forward strategy to catch up with technology and become one of the various trends in the manufacturing technology industry in Indonesia in 2019 carried out by utilizing 3D scanning technology that can accelerate the achievement of 
Indonesia's "innovation-driven economy". Digital reverse engineering applications continue to penetrate various fields such as the home industry, the medical industry, the food industry, any industry will undoubtedly develop and become more personal and custom, especially because of the ease of being reproduced as a result of the development of increasingly sophisticated 3D printers, increasingly personal or sectoral.

According to the Head of BPPT, to be an industrial country, what is needed is innovation. Innovation can be achieved in three ways namely, innovation through research, innovation through engineering design, and innovation through reverse engineering. If Indonesia wants to become an industrial country by relying on basic research it will take a long time. For acceleration, reverse engineering is needed.

\section{Environment}

PLN Pusharlis production process produces Non-B3 Waste (Hazardous and Toxic Material). The government regulation governing waste management is the Decree of the Minister of Manpower of the Republic of Indonesia Number 187 of 2016 concerning the Establishment of the Indonesian National Work Competency Standards in the category of Water Supply, Waste and Recycling Management, Disposal and Cleaning of Waste and Waste from the Waste Management Group in the Field of Industrial Waste Management.

\section{B. Porter's 5 Forces}

The industry is a group of companies that produce products that are the closest substitutes. Analysis of the industry is carried out through Porter's 5 Forces through several aspects including bargaining power of suppliers, bargaining power of buyers, the threat of substitutes, the threat of new entrants, and rivalry among existing competitors. Analysis of the industry will determine the level of attractiveness of the industry that will affect the expected profitability in an industry [4].

\section{- Bargaining Power of Supplier}

PLN Pusharlis as a PLN supporting unit engaged in the design and reverse engineering of electrical equipment has a Low Bargaining Power of Supplier. This happens because PLN Pusharlis will choose suppliers who offer competitive/inexpensive raw material prices with good quality and specifications by PLN Pusharlis desires. So, if there are suppliers who offer products with appropriate specifications, good quality, and at low prices, it will be an option to be used as a supplier of raw materials.

\section{- Bargaining Power of Buyers}

Bargaining power of buyers PLN Pusharlis in selling services in the form of design and reverse engineering is Low to Moderate. This happens because customers of PLN Pusharlis are work units of PLN (Region, Distribution, Transmission, Power Plant) and its subsidiary that has been appealed by the Central PLN to cooperate with PLN Pusharlis.

\section{- Threat of Substitute}

The threat of substitutes still tends to be Moderate. This happens because there are still identical companies that can be the choice to produce the products needed if they have good quality and low prices (according to the agreement). So that the level of substitute threats is important to note because there is no dependence on selected companies, outside the Central PLN regulation which appeals to the work unit of PLN and its subsidiaries to work with PLN Pusharlis to meet the needs of electrical equipment.

\section{- Threat of New Entrants}

The challenge to enter into manufacturing industry in the field of design and reverse engineering is quite difficult because it requires sophisticated technology and currently the Central PLN regulation has been applied which states that all PLN units must collaborate with PLN Pusharlis to produce electrical equipment needs, so the threat of new entrants still tends to be Low. This happens because it takes a large cost to provide qualified technology to be able to produce good quality products.

- $\quad$ Rivalry Among Existing Competitor

Manufacturing industry competition in the field of design and reverse engineering at this time is quite High considering the reverse engineering activities have been supported by the government especially the Agency for the Assessment and Application of Technology (BPPT) in accelerating innovation. This causes many companies to do reverse engineering methods as a form of accelerating innovation, but what distinguishes between companies is the technology they have, the quality they produce, and the price offered. Therefore, the level of competition with competitors is quite high.

\section{BUSINESS-LEVEL STRATEGY}

Each company must develop and implement a businesslevel strategy to gain competitive advantage by utilizing core competencies in certain markets to create a difference and the company's position with its competitors, whether it intends to perform activities differently or to perform different activities [5]. There are five types of business-level strategies that companies must choose to build and maintain the desired strategic position against competitors, including Cost Leadership, Differentiation, Focused Cost Leadership, Focused Differentiation, and Integrated Cost Leadership/Differentiation [5].

Based on the explanation of the five business-level strategies above and as discussed in the previous chapter, Integrated Cost Leadership/Differentiation Strategies will be the right strategy for PLN Pusharlis seeing the purpose of using this strategy is to produce products efficiently with several different features. Besides that, the Integrated Cost Leadership/Differentiation strategy is in line with one of PLN Pusharlis' missions is providing optimal added value to the PLN Group by optimizing the cost efficiency and meeting the needs of developing innovative works to support the growth of the domestic industry. The form of cost leadership strategy that can be generated by PLN Pusharlis is to streamline PLN's operating costs, especially maintenance and investment costs, and streamline assignment costs such as the addition of new equipment or machinery to reduce workmanship in external workshops and increase HR competency. While the form of differentiation strategy that can be generated by PLN Pusharlis is to utilize the reverse engineering method as one of the methods of acceleration of Electricity Infrastructure 
Development.

Besides, another reason for choosing Integrated Cost Leadership/Differentiation strategy for PLN Pusharlis is that PLN Pusharlis has a workflow process role in the form of reverse engineering (RE), manufacturing, quality control, and quality assurance or abbreviated as ReMQC \& QA, which is used as a target to provide added value to asset owners namely PLN and generating units. So that PLN Pusharlis must be able to provide options and benefits for asset owners to improve cost efficiency and increase the useful life of assets through reverse engineering, repair and reconditioning programs that result in the age and lifetime of assets that can be extended, and there will be an increase in availability and reliability that results in increased production. Also, related to the PLN's duty from the government to reduce the cost of electricity supply, in line with PLN's business portfolio, according to the company's long-term report, the outline of PLN Pusharlis' strategy in the next five years is to optimize cost efficiency, especially for PLN maintenance costs, where PLN Pusharlis is projected to be a unit that handles manufacturing for generating, transmission and distribution equipment that contributes to increasing the Domestic Component Level by utilizing reverse engineering capabilities and maximizing the use of assets through strategic partnerships with other equipment manufacturers.

Therefore, by proposing an Integrated Cost Leadership/Differentiation strategy for PLN Pusharlis is important because PLN Pusharlis is PLN's backbone, a source of differentiation or uniqueness from PLN, so PLN's future development must be supported primarily by engineering including PLN Pusharlis. In addition to supporting PLN Pusharlis's mission, namely (1) providing optimal added value to the PLN Group, by carrying out related activities, to ensure business continuity, optimization of cost efficiency, superior capability in the industry, increase in profit contribution, and/or development of new businesses, (2) carrying out a quality control system on repair, reverse engineering, and manufacturing of electrical components to support PLN's performance to ensure the availability of reliable and efficient power supplies, and (3) acting to meet the needs of emergency repair and development of innovative works that support the growth of the domestic industry. Where this strategy will also be used as an action by PLN Pusharlis in competing in its industry and based on the company's long-term report, in 2021 PLN Pusharlis will become a subsidiary so that this strategy is expected to be able to support PLN Pusharlis in conducting its business in the electricity sector.

\section{TOWS ANALYSIS}

TOWS matrix is a matrix that illustrates how the conditions of opportunities and threats faced by the company can be adjusted to the conditions of the company's strengths and weaknesses so that they can generate strategic alternatives [5]. Four alternative strategies can be generated by TOWS Matrix, namely SO Strategies, WO Strategies, ST Strategies, and WT Strategies. SO (Strengths-Opportunities) Strategies are strategies that use the company's strengths to take advantage of opportunities faced by the company. WO
(Weakness-Opportunities) Strategies are strategies that overcome the company's weaknesses by utilizing existing opportunities. ST (Strengths-Threats) Strategies are strategies that use the company's strengths to avoid threats faced by the company. WT (Weakness-Threats) Strategies are strategies that aim to reduce the company's weaknesses and minimize the threats that occur [6]. The following is a TOWS analysis PLN Pusharlis:

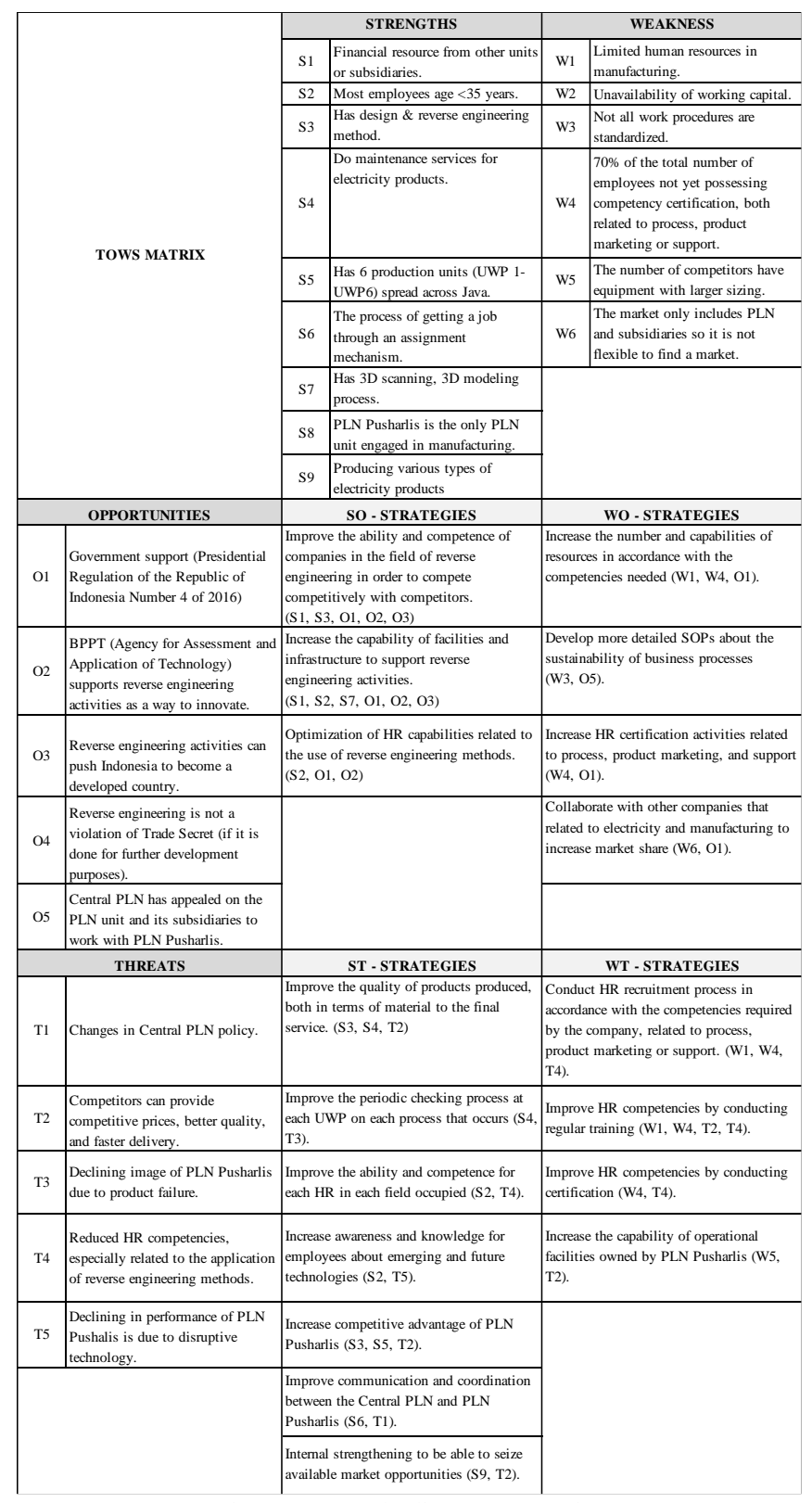

Fig. 1. PLN Pusharlis TOWS Matrix.

\section{CONCLUSION}

PLN Pusharlis is one of the PLN units that supports the 35,000 MW program. PLN Pusharlis focuses on fulfilling roles in Reverse Engineering, Manufacturing, and Quality Control of power plant equipment. To support the fulfillment of the electricity part of the 35,000 MW program, PLN Pusharlis must have the right strategy in carrying out its business. So, to find out this strategy an analysis of the company's environmental conditions through external and internal analysis is needed. External analysis is 
carried out to determine opportunities and threats that occur, both in the macro, industrial and competitive environments. External analysis in this study is carried out through PESTLE Analysis and Porter's 5 Forces. Whereas in internal analysis, there are two main scopes, namely resource analysis, and value chain activity, which are used as the basis for superior capabilities and competencies in achieving a competitive advantage.

After analyzing the company's environmental conditions and discovering the problems that occur, then a business strategy formulation is carried out using the TOWS Matrix. The business strategy formulation aims to find out the company's position and create a competitive advantage.

Therefore, the suitable business-level strategy that can be implemented for PLN Pusharlis to support 35,000 MW project is Integrated Cost Leadership/Differentiation Strategies because the purpose of using this strategy is to produce products efficiently with several different features. Besides that, the Integrated Cost Leadership/Differentiation strategy is in line with one of PLN Pusharlis' mission is providing optimal added value to the PLN Group by optimizing the cost efficiency and meeting the needs of developing innovative works to support the growth of the domestic industry. The form of cost leadership strategy that can be generated by PLN Pusharlis is to streamline PLN's operating costs, especially maintenance and investment costs, and streamline assignment costs such as the addition of new equipment or machinery to reduce workmanship in external workshops and increase HR competency. While the form of differentiation strategy that can be generated by PLN Pusharlis is to utilize the reverse engineering method as one of the methods of acceleration of Electricity Infrastructure Development.

\section{REFERENCES}

[1] Ministry of Energy and Mineral Resources, Directorate General of Electricity, August 2019. [Online]. Available: https://gatrik.esdm.go.id/frontend/download_index/?kode_category=st atistik. [Accessed 5 July 2020].

[2] L. M, "Indonesia Needs to Immediately Implement Innovation-Based Economy," 13 September 2018. [Online]. Available: Indonesia Perlu Segera Terapkan Ekonomi Berbasis Inovasi. [Accessed 5 July 2020].

[3] H. Friana, "Sri Mulyani's strategy to increase GDP in Indonesia," tirto.id, 3 April 2019. [Online]. Available: https://tirto.id/strategi-srimulyani-agar-gdp-di-indonesia-naik-dkWZ. [Accessed 5 July 2020].

[4] H. Wandebori, "Industry Analysis," in Manajemen Strategi Dalam Perspektif Indonesia - Konsep dan Studi Kasus, Bandung, ITB Press, 2019 , p. 49.

[5] M. A. Hitt, R. D. Ireland and R. E. Hoskisson, "Business-Level Strategy," in Strategic Management: Concept and Cases: Competitiveness \& Globalization, 12ed, Cengage Learning, 2016, pp. 111-129.

[6] T. L. Wheelen and J. D. Hunger, "Generating Alternative Strategies by Using a TOWS Matrix," in Strategic Management and Business Policy: Toward Global Sustainability, 13th Edition, Prentice-Hall, 2012, pp. 182-283.

[7] Agency for the Assessment and Application of Technology (BPPT), " Head of BPPT: Focus on Programs That Have National Impact," 16 August 2016. [Online]. Available: https://www.bppt.go.id/layananinformasi-publik/2691-kepala-bppt-fokus-pada-program-yangmemiliki-dampak-nasional. [Accessed 1 Februari 2020].

[8] Agency for the Assessment and Application of Technology (BPPT), "Science and Technology Innovations to Encourage Domestic Industry, Realizing Pancasila Economy" 9 May 2018. [Online]. Available: https://www.bppt.go.id/layanan-informasi-publik/3171 inovasi-iptek-untuk-mendorong-industri-dalam-negeri-mewujudkanekonomi-pancasila. [Accessed 10 April 2020].

[9] Ministry of SOE's Legal Documentation and Information Network, "General Guidelines for the Procurement of Goods and Services for
State-Owned Enterprises," [Online]. Available: http://jdih.bumn.go.id/lihat/PER-08/MBU/12/2019. [Accessed 6 August 2020].

[10] Ministry of SOE's Legal Documentation and Information Network, "Amendments to the Regulation of the Minister for State-Owned Enterprises Number PER-03/MBU/08/2017 concerning Guidelines for Cooperation with State-Owned Enterprises," [Online]. Available: http://jdih.bumn.go.id/lihat/PER-04/MBU/09/2017. [Accessed 6 August 2020].

[11] Agency for the Assessment and Application of Technology (BPPT), "BPPT-PLN: Encouraging the Competitiveness of the Manufacturing Industry in the Electricity Sector," [Online]. Available: https://www.bppt.go.id/index.php/profil/organisasi/937-bppt-plndorong-daya-saing-industri-manufaktur-bidang-ketenagalistrikan. [Accessed 1 February 2020].

[12] P. Kotler and G. Armstrong, Principles of Marketing - 14th Edition, New Jersey: Prentice-Hall, 2011.

[13] PT PLN (Persero), "Annual Report," [Online]. Available: https://web.pln.co.id/stakeholder/laporan-tahunan. [Accessed 5 January 2020].

[14] A. Osterwalder, Y. Pigneur, G. Bernarda and A. Smith, Value Proposition Design: How to Create Products and Customer Want, Hoboken, New Jersey: John Willey \& Sons, Inc, 2014.

[15] Ministry of SOE's Legal Documentation and Information Network, "PERPRES Number 4 of 2016," [Online]. Available: http://jdih.bumn.go.id/. [Accessed 8 January 2020].

[16] PT PLN (Persero) Electricity Maintenance Center, [Online] Available: http://pln-pusharlis.co.id.

[17] D. A. Putra, "Coordinating Minister Luhut alludes to PLN because of the low of Domestic Component Level," 2 September 2019. [Online]. Available: https://www.merdeka.com/uang/menko-luhut-sentil-plnkarena-rendahnya-tkdn.html. [Accessed 14 May 2020].

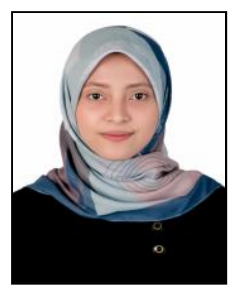

Rizka Malia Khulda was born on December 6 1996, in Kudus, Central Java, Indonesia. She earned a bachelor's degree from Telkom University in 2018 majoring in Industrial Engineering.

She is currently pursuing her master's degree in Master of Business Administration at Bandung Institute of Technology, Indonesia. She has work experience as an intern at PT PLN (Persero) Electricity Maintenance Center or PLN Pusharlis in 2016 for three months in the business plan division.

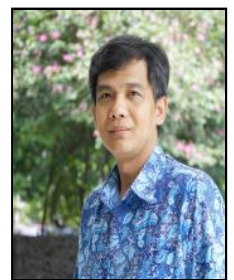

Harimukti Wandebori earned his doctoral program in Management from the University of Twente, Netherlands in 2016. He obtained his MBA from Maastricht School of Management, Netherlands in 2001. He earned a Bachelor's degree in Materials Electrical Engineering from Bandung Institute of Technology in 1990.

$\mathrm{He}$ is currently a lecturer at School Business and Management, Bandung Institute of Technology (SBM ITB), and a member of the Business Strategy and Marketing Interest Group. His research interest is strategic management. He has made many articles both in national and international journals with the theme of strategic management, strategic alliances, and marketing management. He has published a textbook entitled "Manajemen Strategi Dalam Perspektif Indonesia. Konsep dan Studi Kasus" in 2019. 